\title{
El poder de la creación de imágenes sonoras: cómo la radio contó la crisis del euro
}

\author{
The power of sound images: radio storytelling during euro crisis
}

\author{
Dr. Juan Pablo Colmenarejo \\ Universidad de Navarra | Campus Universitario, 31009 Pamplona | España | \\ https://orcid.org/0000-0002-3777-9156 | colmenarejojpablo@gmail.com
}

\author{
Dra. María del Pilar Martínez-Costa \\ Universidad de Navarra | Campus Universitario, 31009 Pamplona | España | \\ https://orcid.org/0000-0002-6564-0207 | marcosta@unav.es
}

Fechas | Recepción: 01/06/2021 | Aceptación: 23/09/2021

\section{Resumen}

La radio es un medio que dispone exclusivamente del sonido y de la construcción de imágenes sonoras para elaborar sus mensajes. Lo hace desplegando una variedad de recursos lingüísticos, con un alto poder evocador. Mediante la construcción de metáforas conceptuales, que permiten concretar nociones abstractas, la radio consigue explicar y mostrar la realidad, a través de representaciones sonoras de la vida cotidiana de sus oyentes. Cuanto más complejo es el tema de la actualidad, la radio recurre con más frecuencia a las metáforas conceptuales -mediante la acumulación de recursos y la redundancia - para recrear las imágenes que lo expliquen. El objetivo de este trabajo es describir y caracterizar cómo la radio informó de la crisis del euro a través de la creación de imágenes sonoras. Desde una aproximación cuantitativa y cualitativa, se analiza la construcción de la metáfora conceptual 'La crisis es una guerra' en la tertulia El equipo económico de La linterna de la Cadena COPE de mayo de 2010 a julio de 2012, período central de la crisis del euro en España. En la construcción de dicha metáfora conceptual y las imágenes sonoras asociadas

\section{Abstract}

Radio is still a media whose messages depend exclusively on sound and sound images. And it achieves it by unfolding a variety of visual and conceptual language resources with a high evocative power. By building conceptual metaphors, which allow it to turn abstract notions into specific ones, radio gets to explain and show reality through sound images, making use of its audience's everyday life. When news is too complex, radio resorts more frequently to conceptual metaphors-gathering resources and redundancies- for reproducing the images which explain them. The aim of this research is to describe and characterize how radio reported on the euro crisis by creating sound images. From a quantitative and qualitative approach, it analyses the construction of the conceptual metaphor THE CRISIS IS A WAR on the radio programme "El equipo económico de $L a$ linterna" in Cadena COPE from May 2010 to July 2012, the main phase of the euro crisis in Spain. In the construction of that conceptual metaphor and the related sound images, it is specifically analysed the symbols and notions allocated to the term "rescue", whose explanations were key to show -at first as a "rescue operation" and then as an "invasion"- the crisis development. 
se estudian los atributos y conceptos adjudicados a la expresión "rescate", cuya explicación fue importante para mostrar la evolución de la crisis, primero como una "operación de salvamento", y luego como una "invasión". El estudio concluye que la forma de contar de la radio, recurriendo a imágenes próximas al oyente, refuerza su poder informativo para explicar una realidad compleja.

Palabras clave: radio, imágenes sonoras, narrativa radiofónica, metáforas conceptuales, periodismo económico.
The study concludes that radio storytelling, using images close to the listener, reinforces its informative power to explain a complex reality.

\section{INTRODUCCIÓN}

Con el primer acuerdo de préstamo a Grecia concretado el 2 de mayo 2010, los países europeos iniciaron una política de asistencia financiera y ajustes macroeconómicos sin precedentes. Este primer "rescate" marcó un punto de inflexión en la crisis económica global que se había iniciado tres años antes, al conocerse todo un entramado de productos hipotecarios de alto riesgo con origen en Estados Unidos, y que se trasladó a una Europa altamente endeudada generando desconfianza en su moneda única. A partir de ese momento, el término "rescate", junto a otros atributos bélicos, se incorporaría al lenguaje de los medios y muy pronto a la vida cotidiana de los ciudadanos.

La crisis de la eurozona duraría diez años hasta el 9 de agosto de 2017, cuando la Comisión Europea da oficialmente por superada una depresión que había supuesto hasta ese momento la peor crisis de su historia. Durante ese periodo, los medios de comunicación explicaron la realidad económica haciendo uso de diferentes recursos lingüísticos que hicieran posible comprender la realidad. Uno de estos recursos fue la construcción de metáforas conceptuales. Entendidas como esquemas abstractos que combinan variedad de expresiones lingüísticas concretas, activan mecanismos de asociación mental entre unos elementos con otros para explicar realidades menos conocidas (Lakoff y Johnson, 1991; Calsamiglia y Tusón, 1999; Llamas, 2005; Soriano, 2012).

No era la primera vez que el periodismo y los medios de comunicación hacían uso de la metáfora conceptual para explicar la economía. Desde su origen, el discurso o storytelling de la economía ha encontrado en las metáforas, comparaciones y alegorías formas concretas para comprender y explicar los fenómenos económicos, caracterizados por ser abstractos y complejos (Henderson, 1982; Strassmann, 1993; Charteris-Black y Ennis, 2001; Sarmiento, 2007; Herrera Soler, 2008; Orts-Llopis y Almela, 2009; Rojo-López y Orts-Llopis, 2010; Williams, 2013; Shiller, 2019; entre otros). Sin embargo, la crisis del euro se planteaba como "un magnífico campo de pruebas para experimentar" (Arrese, 2015, p.19). También para la radio, que es un medio que dispone exclusivamente del sonido y de la construcción de imágenes sonoras para elaborar sus mensajes, desplegando una variedad de recursos lingüísticos, con un alto poder evocador, tanto visual como conceptual.

Mediante la construcción de metáforas conceptuales, que permiten concretar nociones abstractas, la radio consigue explicar y mostrar a través de imágenes sonoras la realidad, a 
través de representaciones de la vida cotidiana de sus oyentes. El empleo de estos recursos lingüísticos y la construcción de estas imágenes se incrementa en momentos álgidos de información. Cuanto más complejo es el tema de la actualidad, la radio recurre con más frecuencia a las metáforas conceptuales -mediante la acumulación de recursos y la redundancia - para recrear las imágenes que lo expliquen (Colmenarejo y Martínez-Costa, 2020). El incremento del uso de los recursos para contar al oyente una realidad permite sumar aspectos y perspectivas que desarrollan y profundizan en la explicación, redundando en lo esencial.

\subsection{Objetivo}

En este contexto, el objetivo de este trabajo es describir y caracterizar cómo la radio informó de la crisis del euro a través de la creación de imágenes sonoras asociadas a la construcción de la metáfora conceptual 'La crisis es una guerra'. Se estudian particularmente los atributos y conceptos adjudicados a la expresión "rescate", cuya explicación fue importante para mostrar la evolución de la crisis, primero como una "invasión" y luego como una "operación de salvamento".

\subsection{Metodología}

Se eligió, como caso de estudio, la tertulia El equipo económico de La linterna de la Cadena Cope durante el período mayo de 2010 a julio de 2012, considerado el momento más álgido de la crisis del euro. Desde el punto de vista informativo esta etapa se inicia con el rescate a Grecia y termina cuando el Banco Central Europeo intervino en defensa del euro y cierra la etapa de los rescates.

Para la selección del caso de estudio se tuvo en cuenta la continuidad y permanencia en antena del espacio de economía en La linterna -18 temporadas ininterrumpidas entre 20002018-; los datos de audiencia - consolida una audiencia de 250 mil oyentes durante esos años, según el Estudio General de Medios-; así como la disponibilidad de los archivos con los guiones del programa y el acceso a los audios emitidos en la web de la cadena.

El trabajo ha utilizado una metodología mixta. En primer lugar, un análisis de contenido cuantitativo para explorar, describir e inferir tendencias en el empleo de los recursos lingüísticos en los 384 programas emitidos durante esos 27 meses. En segundo lugar, un estudio cualitativo de análisis de la conversación espontánea entre los participantes de la tertulia, focalizado en el estudio de las metáforas conceptuales generadas para explicar la crisis económica.

Para ello se localizaron, escucharon y transcribieron los audios de los programas, que sumaban 245 horas y 45 minutos. Seguidamente un primer codificador procedió a registrar y organizar el material por temas y recursos lingüísticos empleados por los participantes de la tertulia, identificando como unidad de análisis cada uno de los recursos lingüísticos registrados. Se obtuvo una muestra de 1.189 unidades que fueron verificadas por un segundo codificador y distribuidas en tablas de contingencia utilizando la herramienta del programa estadístico SPSS con el fin de hallar las frecuencias de cada una de las variables (fecha, participante, perfil profesional, tema, recurso lingüístico y metáfora conceptual) y buscar conexiones relevantes entre las categorías identificadas. De esta forma se registraron las metáforas conceptuales más frecuentes y se seleccionó la metáfora conceptual 'La crisis es una guerra' para realizar el 
estudio cualitativo de las expresiones metafóricas e imágenes sonoras utilizadas en su construcción. Así, se consideró el tema o hecho noticioso como "dominio origen" o "fuente", y la imagen que se genera en el destinatario como "dominio destino" o "meta", desglosando los componentes de ambos dominios: actor/es, acción/es, afectado/s, lugar/es, etc.

\section{CONTEXTO INFORMATIVO Y MARCO TEÓRICO}

\subsection{Los hitos del "rescate" en la crisis del euro}

La crisis financiera iniciada en agosto de 2007 evolucionó a una crisis de deuda soberana en los países de la zona euro, derivando a su vez en otra crisis de la economía real. Entre mayo de 2010 y junio de 2012, la Unión Europea, el Banco Central Europeo y el Fondo Monetario Internacional -la denominada Troika- acordaron planes de préstamos, condicionados a un fuerte control de la política económica y de las finanzas públicas de los gobiernos que recibieron dichas ayudas: Grecia, Irlanda y Portugal, que recibieron un "rescate" total; y España, que recibió un "rescate" parcial. Las ayudas a España se destinaron al saneamiento de las cajas de ahorro que, hasta ese momento, representaban la mitad del sistema financiero español (Pin, 2017). Con el mecanismo de las ayudas o "rescates" en marcha, los países del centro y el norte del euro, liderados por Alemania, impusieron una política de austeridad a los países del sur e Irlanda.

El primer "rescate" a Grecia tuvo lugar en mayo de 2010 y supuso la creación de un fondo institucional dotado de 110 mil millones de euros. Mediante la creación de un Fondo de Estabilidad Financiera, la Unión Europea amplió la dotación a 750 mil millones, con aportaciones del Fondo Monetario Internacional y para devolver la calma a los mercados financieros, que temían el contagio y la necesidad de nuevos "rescates". La subida del precio de la deuda en Grecia con el incremento de la prima de riesgo -el sobreprecio a pagar en comparación con el bono alemán- se extendió a Irlanda, Portugal y España.

Para hacer frente a esta incertidumbre en los mercados, el gobierno español aprobó un primer ajuste -recorte de gastos y subida de impuestos- a petición de la UE, Estados Unidos y China. De esta forma, el foco de los acreedores se situó en Portugal. Su deuda a diez años subió hasta el 6,42 \%, el máximo desde la creación del euro en 2002. Además de Portugal, los mercados financieros presionaron aún más la deuda de Irlanda, incapaz de hacer frente a las necesidades de liquidez de su sistema bancario. Entre octubre y diciembre de 2010 se aprobó el plan de "rescate" a Irlanda con la inyección de 85 mil millones de euros. Poco después, en el primer semestre de 2011, el Estado portugués solicitó una ayuda de 78 mil millones de euros y Grecia un segundo "rescate" de 100 mil millones.

Una vez consumados los dos "rescates" a Grecia, y los de Irlanda y Portugal, la Troika advirtió a España de los riesgos que suponían para su economía las subidas constantes de la prima de riesgo durante 2010 y 2011. Así, la principal característica de la crisis en España no fue su intensidad sino su persistencia (Buesa, 2011). En el caso español, primero fue una crisis económica general y, después, se produjo una crisis financiera (Juan, 2011). Por ello, en febrero de 2012 España realizó un primer "auto-rescate", con la aprobación de una reforma laboral que buscaba flexibilizar el mercado de trabajo y así conseguir un incremento del empleo y de la actividad económica. Para hacer frente a la crisis financiera fue necesario un "rescate" institucional parcial que se concretó con una línea de crédito europeo de hasta 100 mil millones de euros, de los que España utilizó 42 mil millones para financiar la 
transformación de las cajas de ahorro en bancos privados (Colmenarejo, 2020).

En todo este proceso, la intervención directa del presidente del Banco Central Europeo, Mario Dragui -en defensa de la moneda única con su célebre frase whatever it takes (lo que sea necesario)- consiguió cerrar en el verano de 2012 la etapa de los "rescates", y sentar las bases para la salida de crisis del euro que duraría diez años, hasta 2017.

\subsection{La radio y sus formas de contar}

Como se refleja en este breve repaso de los hechos en torno a los rescates financieros a la economía del euro, aparecieron ante el público numerosas expresiones técnicas: sociedad de gestión de activos, banco malo, recapitalización, obligación garantizada por bonos, obligación garantizada de deuda, obligación convertible contingente, participación preferente convertible, agencias de calificación crediticia, deuda subordinada con vencimiento, dación en pago, deflación, decrecimiento, desapalancamiento, derivado, eurobono, instrumentos híbridos de capital, inyección de liquidez, miniempleo, venta en corto descubierta, deuda subordinada sin vencimiento, prociclicidad, fondo soberano, estanflación, deuda estructurada, activo tóxico, troika y fondo buitre. Conceptos y procesos complejos que eran difíciles de explicar.

A la complejidad del lenguaje económico financiero en situaciones de bonanza se añadió el estallido de una crisis que arrastró hasta la opinión pública una serie de expresiones y conceptos, como los anteriores, que empezaron a formar parte de la vida cotidiana. El estallido de la crisis generó una demanda de información por parte del público, que necesitaba saber acerca de unos hechos que le acabarían afectando en su día a día. El periodismo se enfrentaba una vez más a la tarea de adaptar el lenguaje técnico -la jerga económica y financiera- al lenguaje común. En 2009 -el peor año de la crisis en cuanto a caída del crecimiento económico e incremento del paro-, Hernández Gil se refería a la necesidad de volver a lo esencial, a sopesar las palabras entre las manos antes de lanzarlas atropelladamente al vacío. La crisis, explicaba Hernández Gil, es "una palabra a cuyo uso hemos perdido el miedo", obliga al rigor y a la mirada atenta a nuestro alrededor (2009, p.3). Es así como, una vez más, el periodismo y los medios de comunicación recurren a la construcción de metáforas conceptuales para explicar la crisis de la economía.

Las metáforas conceptuales, sus casos individuales, y las expresiones metafóricas son empleadas por el periodismo para conseguir el objetivo de trasladar la información económica desde lo complejo a lo sencillo. La palabra "metáfora", afirma De Miguel (2013, p.151), indica el traslado de la imaginación a otro círculo de ideas emparentadas con las que se expresan. El ciudadano, habitualmente desinteresado por cuestiones como la bolsa, las hipotecas basura o los mercados de capitales, busca las claves que le permitan conocer e interpretar los acontecimientos. La prensa escrita ha usado con frecuencia las metáforas conceptuales para explicar la economía. Arrese y Vara (2015) mencionan varias categorías: procesos de salud y enfermedad, fenómenos y desastres naturales, sucesos con artefactos y construcciones, guerras y enfrentamientos, deportes, juegos y entretenimientos, y acciones y situaciones de seres vivos. La crisis del euro puso nuevamente a prueba el uso de recursos lingüísticos para explicar la realidad.

Para la radio, el desafío siempre es doble. Por un lado, en el proceso de producción solo cuenta con el sonido para estimular la creación de imágenes mentales. Por el otro, tiene que 
conseguir generar una respuesta en el oyente, que le permita "restablecer o restituir esos componentes visuales ausentes", a partir de sus referentes y experiencia previa (Rodero, Pérez-Maillo y Espinosa de los Monteros, 2019, p.154). Esa experiencia auditiva posee además un fuerte componente emocional. Junto a la información, la radio es capaz de transmitir emociones y crear vínculos entre quien habla y quien escucha (Rodero, 2018 y 2020).

Por ello, se puede afirmar que existe una correspondencia entre las metáforas conceptuales como construcciones lingüísticas y las imágenes sonoras que genera la radio para explicar la realidad, y donde el "dominio origen" es la información que hay que explicar, y el "dominio meta" la imagen sonora que se traslada al oyente para explicarla.

\section{RESULTADOS}

El análisis realizado en la tertulia especializada El equipo económico de La linterna de la Cadena Cope durante el período más agudo de la crisis del euro identificó como más frecuentes 17 tipos de metáforas conceptuales para explicar la crisis en términos próximos a la vida cotidiana y relacionados con los siguientes ámbitos: Construcción, Deporte/Boxeo, Deporte/Fútbol, Deporte/Hípica, Deporte/Motor, Deporte/Otros, Doméstica/Burbuja, Educación, Fiesta, Guerra, Jardinería, Juego, Justicia, Mecánica, Naturaleza/Río, Salud y Taurina. Estas temáticas sobre las que se construyeron metáforas conceptuales en torno a la crisis agruparon 642 de los 1.189 recursos registrados, 111 de los cuales se referían a la crisis en términos de "enfrentamiento bélico". Este trabajo se ciñe al estudio de las imágenes de la expresión "rescate", que fue predominante en la construcción de la metáfora conceptual "La crisis es una guerra'.

Así, el gráfico 1 muestra la frecuencia de aparición de las expresiones metafóricas según los temas noticiosos abordados en términos de "conflicto" y "enfrentamiento", durante el período analizado. Entre ellos, los mecanismos de ayudas a los países con incrementos acelerados de su deuda soberana, así como las reformas asociadas -lo que se denominó "rescate"- son muy recurrentes: 40 de los 111 recursos identificados. 


\section{Gráfico 1}

La construcción de la metáfora conceptual 'La crisis es una guerra' según temática de las noticias $(n=111)$

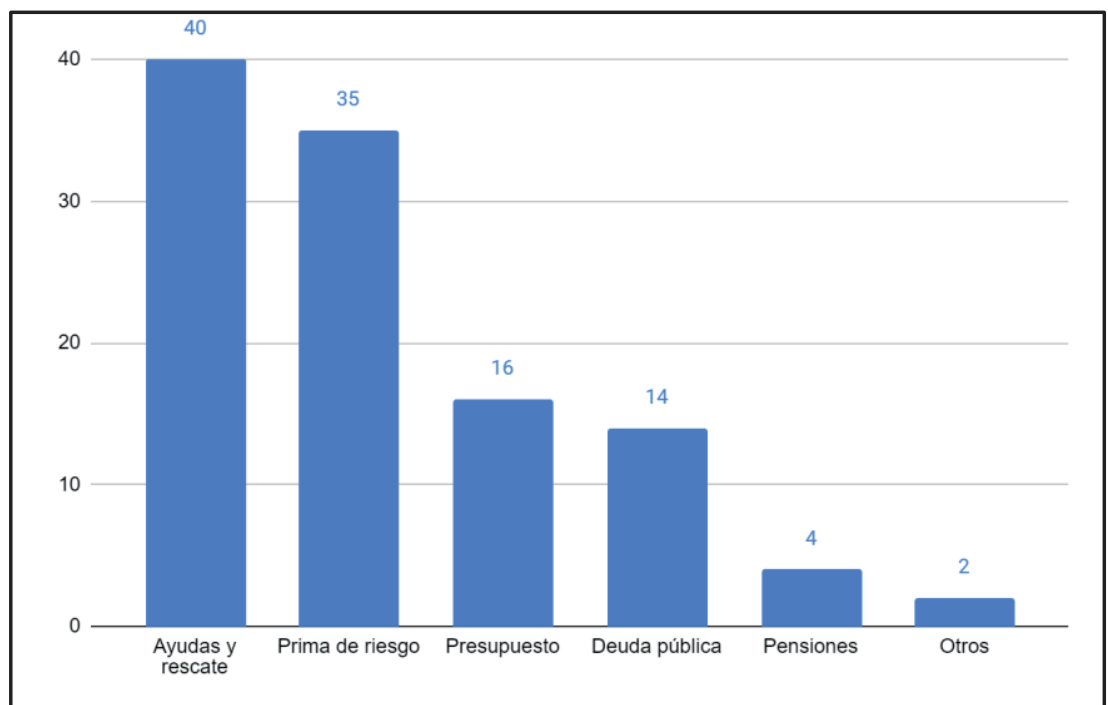

Fuente: elaboración propia.

Como se ha señalado antes, el término "rescate" formó parte del lenguaje político y económico de esta etapa. Durante los meses estudiados tuvieron lugar los acuerdos de préstamos a los estados de Grecia, Irlanda y Portugal, así como al sector financiero español.

Así la metáfora conceptual 'La crisis es una guerra' se construyó a partir de las imágenes sonoras del "enfrentamiento", la presencia de "bandos" en conflicto y el "rescate". Este último entendido primero, como "operación de salvamento", y luego, como "invasión", con el fin de atribuir una configuración concreta y reconocible a la realidad que se quería explicar.

En la siguiente tabla se presenta una selección de las expresiones metafóricas que crearon la metáfora conceptual 'La crisis es una guerra', así como las imágenes sonoras resultantes correspondientes al "rescate" y sus atributos.

Tabla 1

Las imágenes sonoras del rescate

\begin{tabular}{|l|l|l|l|}
\hline Fecha & $\begin{array}{l}\text { Domino origen o fuente } \\
\text { (hecho noticioso) }\end{array}$ & $\begin{array}{l}\text { Expresión metafórica } \\
\text { textual* }\end{array}$ & $\begin{array}{l}\text { Dominio destino o meta } \\
\text { (imagen sonora)** }\end{array}$ \\
\hline 06/05/2010 & $\begin{array}{l}\text { El parlamento griego } \\
\text { aprueba el primer plan de } \\
\text { austeridad para afrontar la } \\
\text { crisis. }\end{array}$ & $\begin{array}{l}\text { "Estamos en una } \\
\text { política de sálvese } \\
\text { quien pueda" }\end{array}$ & $\begin{array}{l}\text { La crisis es un campo de } \\
\text { batalla sin reglas }\end{array}$ \\
\hline $10 / 05 / 2010$ & $\begin{array}{l}\text { La UE crea un Fondo de } \\
750 \text { mil millones de euros } \\
\text { para proteger el euro. }\end{array}$ & $\begin{array}{l}\text { "Nos han invadido las } \\
\text { fuerzas económicas } \\
\text { europeas" }\end{array}$ & $\begin{array}{l}\text { El enemigo (mercados/ } \\
\text { acreedores financieros) } \\
\text { toma posiciones en el } \\
\text { campo de batalla (zona } \\
\text { euro) }\end{array}$ \\
\hline $12 / 05 / 2010$ & $\begin{array}{l}\text { España recorta su } \\
\text { presupuesto en 15 mil } \\
\text { millones de euros. }\end{array}$ & $\begin{array}{l}\text { "España se ha } \\
\text { convertido en una } \\
\text { bomba de relojería de } \\
\text { la deuda" }\end{array}$ & $\begin{array}{l}\text { España cada vez debe más } \\
\text { y necesitará un rescate } \\
\text { (dinero) para salvarse }\end{array}$ \\
\hline $16 / 11 / 2010$ & Irlanda pide 100 mil & "La intervención de la & El alto mando (UE) toma \\
\hline
\end{tabular}




\begin{tabular}{|c|c|c|c|}
\hline & $\begin{array}{l}\text { millones de euros a la UE y } \\
\text { el BCE. }\end{array}$ & $\begin{array}{l}\text { Unión Europea en } \\
\text { Irlanda es injerencia y } \\
\text { ayuda" }\end{array}$ & $\begin{array}{l}\text { posiciones (Irlanda) para el } \\
\text { rescate (dinero) }\end{array}$ \\
\hline $22 / 11 / 2010$ & $\begin{array}{l}\text { Se aprueba la ayuda a } \\
\text { Irlanda. }\end{array}$ & $\begin{array}{l}\text { "El rescate a Irlanda } \\
\text { era inevitable" }\end{array}$ & $\begin{array}{l}\text { El rescate (dinero) salva y } \\
\text { evita la derrota (Irlanda) }\end{array}$ \\
\hline $10 / 12 / 2010$ & $\begin{array}{l}\text { El presidente del BCE } \\
\text { afirma que no se han } \\
\text { acabado las reformas. }\end{array}$ & $\begin{array}{l}\text { "No confían porque } \\
\text { España va a ser } \\
\text { rescatada. Los } \\
\text { inversores atacan la } \\
\text { deuda española" }\end{array}$ & $\begin{array}{l}\text { Necesitamos (España) otra } \\
\text { operación de salvamento } \\
\text { para responder al enemigo } \\
\text { (mercados/acreedores } \\
\text { financieros) }\end{array}$ \\
\hline 07/01/2011 & $\begin{array}{l}\text { La ayuda a Portugal no } \\
\text { frena la subida de la prima } \\
\text { de riesgo. }\end{array}$ & $\begin{array}{l}\text { "El rescate a Portugal } \\
\text { será antes que a } \\
\text { España. España ha } \\
\text { recibido golpes antes } \\
\text { de otros rescates" }\end{array}$ & $\begin{array}{l}\text { El frente sur (Portugal) se } \\
\text { salva con el rescate } \\
\text { (dinero). El enemigo } \\
\text { (mercados financieros) } \\
\text { prosigue su ataque } \\
\text { (España) }\end{array}$ \\
\hline $10 / 01 / 2011$ & $\begin{array}{l}\text { El rescate de Portugal es } \\
\text { inminente y hay dudas } \\
\text { sobre España. }\end{array}$ & $\begin{array}{l}\text { "Hay pánico en la } \\
\text { Unión Europea por el } \\
\text { hundimiento de la } \\
\text { economía española" }\end{array}$ & $\begin{array}{l}\text { La economía española es } \\
\text { un barco que se hunde }\end{array}$ \\
\hline $17 / 01 / 2011$ & $\begin{array}{l}\text { La UE estudia ampliar el } \\
\text { fondo de rescate para } \\
\text { poder comprar deuda } \\
\text { soberana. }\end{array}$ & $\begin{array}{l}\text { "La Unión Europea no } \\
\text { puede dejar que los } \\
\text { castillos vayan cayendo } \\
\text { uno detrás de otro" }\end{array}$ & $\begin{array}{l}\text { El alto mando (UE) no } \\
\text { puede permitir más } \\
\text { conquistas del enemigo } \\
\text { (mercados/acreedores } \\
\text { financieros) }\end{array}$ \\
\hline $07 / 03 / 2011$ & $\begin{array}{l}\text { El bono portugués a diez } \\
\text { años está en el 7,65 \% de } \\
\text { interés. }\end{array}$ & $\begin{array}{l}\text { "Si Portugal pide el } \\
\text { rescate se nos cae el } \\
\text { parapeto" }\end{array}$ & $\begin{array}{l}\text { Si Portugal pide el rescate } \\
\text { (dinero), España } \\
\text { necesitará ser salvada }\end{array}$ \\
\hline $23 / 03 / 2011$ & $\begin{array}{l}\text { La deuda de Portugal sube } \\
\text { al } 8 \% .\end{array}$ & $\begin{array}{l}\text { "Portugal va a estar } \\
\text { intervenido de arriba a } \\
\text { abajo" }\end{array}$ & $\begin{array}{l}\text { El alto mando (UE) } \\
\text { interviene (dinero) e } \\
\text { invade Portugal (ajustes } \\
\text { presupuestarios) }\end{array}$ \\
\hline $08 / 04 / 2011$ & $\begin{array}{l}\text { España dice que no hay } \\
\text { riesgo de rescate. }\end{array}$ & $\begin{array}{l}\text { "España es muy grande } \\
\text { para caer" }\end{array}$ & $\begin{array}{l}\text { No habrá invasión } \\
\text { (rescate) a España }\end{array}$ \\
\hline $17 / 06 / 2011$ & $\begin{array}{l}\text { Acuerdo entre Alemania y } \\
\text { Francia en las } \\
\text { negociaciones con Grecia } \\
\text { para el segundo rescate. }\end{array}$ & $\begin{array}{l}\text { "Todo esto es para } \\
\text { evitar que España } \\
\text { caiga" }\end{array}$ & $\begin{array}{l}\text { El flanco español (España) } \\
\text { tiene que hacer esfuerzos } \\
\text { para no caer en manos del } \\
\text { enemigo } \\
\text { (mercados/acreedores } \\
\text { financieros) }\end{array}$ \\
\hline $29 / 06 / 2011$ & $\begin{array}{l}\text { El Parlamento de Grecia } \\
\text { aprueba el nuevo plan de } \\
\text { recortes y subidas de } \\
\text { impuestos. }\end{array}$ & $\begin{array}{l}\text { "Es como si dinamitas } \\
\text { de manera controlada. } \\
\text { Hay que hacer una } \\
\text { quiebra controlada" }\end{array}$ & $\begin{array}{l}\text { El alto mando (UE) invade } \\
\text { e impone condiciones a } \\
\text { Grecia a cambio del } \\
\text { rescate (dinero) }\end{array}$ \\
\hline $11 / 07 / 2011$ & $\begin{array}{l}\text { La prima de riesgo } \\
\text { española sube. }\end{array}$ & $\begin{array}{l}\text { "Estamos en el filo de } \\
\text { la navaja. Se tocan las } \\
\text { líneas rojas del } \\
\text { rescate" }\end{array}$ & $\begin{array}{l}\text { España está en riesgo alto } \\
\text { de ser invadida a través } \\
\text { del rescate (dinero) }\end{array}$ \\
\hline $20 / 07 / 2011$ & $\begin{array}{l}\text { Alemania y Francia } \\
\text { negocian un segundo plan } \\
\text { para Grecia. }\end{array}$ & $\begin{array}{l}\text { "Hay en marcha una } \\
\text { operación de } \\
\text { salvamento" }\end{array}$ & $\begin{array}{l}\text { El rescate (dinero) está } \\
\text { preparado y se puede } \\
\text { producir en cualquier } \\
\text { momento otra invasión }\end{array}$ \\
\hline $10 / 02 / 2012$ & $\begin{array}{l}\text { El Gobierno rebaja la } \\
\text { indemnización por } \\
\text { despido. Primará el }\end{array}$ & $\begin{array}{l}\text { "La reforma laboral es } \\
\text { el salvoconducto que } \\
\text { ha presentado para }\end{array}$ & $\begin{array}{l}\text { La reforma laboral es la } \\
\text { condición pactada con el } \\
\text { alto mando (UE), es un }\end{array}$ \\
\hline
\end{tabular}




\begin{tabular}{|c|c|c|c|}
\hline & convenio de empresa. & $\begin{array}{l}\text { relajar el objetivo de } \\
\text { déficit" }\end{array}$ & auto-rescate que salva \\
\hline $20 / 04 / 2012$ & $\begin{array}{l}\text { La situación de las cajas de } \\
\text { ahorro empeora. España } \\
\text { teme un rescate a la } \\
\text { griega. }\end{array}$ & $\begin{array}{l}\text { "Hemos pasado a } \\
\text { hablar de rescate a } \\
\text { intervención" }\end{array}$ & $\begin{array}{l}\text { España puede ser invadida } \\
\text { (rescate) como Grecia }\end{array}$ \\
\hline $01 / 06 / 2012$ & $\begin{array}{l}\text { La prima de riesgo termina } \\
\text { en máximos, llegando a } \\
\text { superar los } 550 \text { puntos. }\end{array}$ & $\begin{array}{l}\text { "Nos llevan cogidos } \\
\text { por las orejas para el } \\
\text { rescate" }\end{array}$ & $\begin{array}{l}\text { El enemigo } \\
\text { (mercados/acreedores } \\
\text { financieros) quiere obligar } \\
\text { a España a salvarse con el } \\
\text { rescate (dinero) para } \\
\text { evitar la derrota } \\
\text { (expulsión del mercado) }\end{array}$ \\
\hline $23 / 07 / 2012$ & $\begin{array}{l}\text { La prima de riesgo alcanza } \\
\text { los } 640 \text { puntos. El bono a } \\
\text { diez años está en el 7,5 \% }\end{array}$ & $\begin{array}{l}\text { "Estamos rescatados y } \\
\text { hay dos tipos de } \\
\text { rescate, el explícito y el } \\
\text { implícito" }\end{array}$ & $\begin{array}{l}\text { España se salva con un } \\
\text { rescate parcial (dinero) sin } \\
\text { invasión directa, como en } \\
\text { Grecia. }\end{array}$ \\
\hline $26 / 07 / 2012$ & $\begin{array}{l}\text { El presidente del } \mathrm{BCE} \text {, } \\
\text { Mario Dragui, anuncia que } \\
\text { hará lo necesario para } \\
\text { proteger al euro. }\end{array}$ & $\begin{array}{l}\text { "Hay que evitar el } \\
\text { rescate total" }\end{array}$ & $\begin{array}{l}\text { España necesita una } \\
\text { operación de salvamento } \\
\text { (dinero) pero sin invasión } \\
\text { (control del Gobierno) }\end{array}$ \\
\hline
\end{tabular}

Fuente: elaboración propia.

*Las expresiones metafóricas textuales de los participantes de la tertulia se presentan entre comillas aquí y en el resto del texto para su identificación.

**Las imágenes concretas a las que hacen referencia las expresiones metafóricas se presentan entre paréntesis aquí y en el resto del texto para marcar su correspondencia con las expresiones metafóricas utilizadas.

Fuente: Guiones y audios del programa La linterna (Cadena Cope, www.cope.es)

\section{DISCUSIÓN Y CONCLUSIONES}

Las expresiones metafóricas que fueron construyendo la metáfora conceptual 'La crisis es una guerra' a lo largo del período estudiado, muestran que la crisis se explicó al oyente con la imagen de un "enfrentamiento bélico", un "combate" sin reglas establecidas en el que participaron, como actores, los mercados financieros y los gobiernos de los países europeos, socios de la moneda única, que dependían de un alto mando común, integrado por la llamada troika (Unión Europea, Banco Central Europeo y Fondo Monetario Internacional). El objetivo común era defender la moneda única, aunque la zona euro se dividió en dos "frentes", norte y sur, que emplearon "armas" diferentes: medidas de austeridad y ajuste en el norte; y más gasto y deuda pública en el sur.

El "enfrentamiento" (crisis) sorprende a los países miembros. Desde la fundación de la moneda única, el 2 de mayo de 1998, no se había producido una situación similar con "ataques" (subidas de la prima de riesgo) que se producían en el "campo de batalla" (zona euro). Dichos "ataques" estaban orientados a "causar bajas" (expulsión del mercado) en los "ejércitos europeos" (países), y a conseguir la solicitud de "rescate" (ayudas) al alto mando (troika).

La imagen del "rescate" (dinero europeo) se presentó al oyente primero como una "operación militar de salvamento", "estamos en una política de sálvese quien pueda", que luego supuso una "invasión": "nos han invadido las fuerzas económicas europeas". El dinero salva, pero con condiciones. El "rescate" (dinero) era implementado por el "alto mando" (troika), socorriendo 
a los "ejércitos europeos" (países) a cambio de una nueva "disciplina militar", más estricta y rigurosa (medidas de ajuste y austeridad): "La Unión Europea no puede dejar que los castillos vayan cayendo uno detrás de otro". La división entre los "bandos europeos", en función de las "armas empleadas" (ajuste/austeridad o gasto público/deuda), trataba de evitar que los "ataques" (subidas de la prima de riesgo) en el "frente débil" (el sur de Europa e Irlanda) permitieran al "enemigo" (acreedores/mercados financieros) derrotar también a los países del "frente fuerte" (Alemania y el norte de la zona euro). En los rescates en 2010 y 2011, la Unión Europea era el "alto mando militar" que desarrollaba "operaciones de intervención" (dinero) en los "flancos del frente sur", Grecia, Irlanda y Portugal.

"Salvamento" e "invasión" como atributos del rescate, así se explicó en la tertulia: "la intervención de la Unión Europea en Irlanda es injerencia y ayuda", "se va a rescatar a la banca y al Estado irlandeses" y "el rescate a Irlanda era inevitable porque no tenía suficiente dinero". La ayuda estaba condicionada al cumplimiento de una nueva "disciplina militar" (medidas de ajuste) impuesta por el "alto mando" (Unión Europea). En el caso de España, el "alto mando" intervino sin tomar el control del ejército (España), que fue quien aplicó esa nueva disciplina (ajustes presupuestarios): "Hay en marcha una operación de salvamento".

Por lo tanto, el "rescate" (dinero) se realizó teniendo en cuenta el tamaño (Producto Interior Bruto) de los ejércitos (países). El "alto mando" (Unión Europea) proporcionó ayuda (dinero), pactó treguas (compras deuda) e impuso unas condiciones (medidas de ajuste/disciplina presupuestaria) en el flanco débil: "Portugal va a estar intervenida de arriba abajo". Por su parte, España flexibilizó su mercado laboral a cambio de tener más tiempo para rebajar el déficit y, por lo tanto, la deuda acumulada cada año por el Estado: "Todo esto es para evitar que España caiga". El auto-rescate (reforma laboral), que fue "el salvoconducto" para relajar el déficit, resultó insuficiente, ya que los ataques (subidas de la prima de riesgo) continuaron para conseguir la derrota (expulsión del mercado) y provocar la intervención del alto mando (Unión Europea) con una operación de salvamento (dinero) en el flanco español: "Nos llevan cogidos por las orejas camino del rescate", "habrá rescate de la economía española en el 11 o en el 12" y "estamos en el filo de la navaja. Se tocan las líneas rojas del rescate". La operación de salvamento (dinero) del flanco español se produce sin la invasión (control del presupuesto), tal y como se realizó en el resto de los flancos del frente sur (Grecia, Irlanda y Portugal), pero con condiciones específicas de ajuste para España: "Estamos rescatados y hay dos tipos de rescate, el explícito y el implícito". Se explicó en la tertulia que, además del préstamo europeo para pagar la quiebra de las cajas de ahorro, el alto mando (Unión Europea y Banco Central Europeo) ayudó a España alcanzando una tregua (compra de deuda española en el mercado) con el enemigo (acreedores): "Hay que evitar el rescate total", como un rescate (dinero) implícito. El rescate (dinero) español fue parcial y tuvo una finalidad (salvar las cajas de ahorro): "hay pánico en la Unión Europea por el hundimiento de la economía española". Italia, con una economía más grande que la de España, no fue objeto de ningún rescate explícito; aunque la declaración del presidente del Banco Central Europeo, el 26 de julio de 2012, anunciando que haría todo lo posible para "salvar el euro" (compras de deuda a los acreedores en los mercados), fue considerada para Italia y España -tercera y cuarta economías del euro, respectivamente-como un rescate (dinero) implícito.

Por lo tanto, la metáfora conceptual 'La crisis es una guerra' se estructuró como un conflicto, en el que hay enemigos y batallas. A través del despliegue de las imágenes sonoras del 
enfrentamiento bélico y el rescate (entendido primero como operación de salvamento y luego como invasión) se atribuyó una configuración concreta y reconocible a la realidad que se quería explicar. La imagen del "rescate" (dinero) es doble: positiva y negativa. Por un lado, se salva al derrotado (Estado expulsado del mercado) para después dotarse de armamento (medidas de política económica) para hacer frente al enemigo (acreedores financieros).

En momentos de crisis se acude al lenguaje de la guerra, donde hay siempre un enemigo al que hacer frente. Como en la crisis del euro, con la pandemia del COVID-19 y ante la necesidad de explicar a la opinión pública un fenómeno complejo, se ha recurrido a las imágenes del conflicto bélico (guerra, batalla o lucha contra el virus). La radio, una vez más, ha cumplido un papel relevante en la cobertura de la pandemia (De Sola Pueyo, 2021) y refuerza su poder y credibilidad informativa para explicar realidades complejas. En este escenario de crisis sanitaria, desde la política se ha evitado utilizar la imagen del "rescate", que se ha sustituido por la de "reconstrucción" apelando a los referentes visuales y emocionales del final de la Segunda Guerra Mundial. A diferencia del fondo de rescate de la crisis del euro, hecho con las aportaciones de los Estados miembros, el BCE y el FMI; la Comisión Europea, se ha endeudado por primera vez como institución, para dotar con 750 mil millones de euros al plan de reconstrucción "Next Generation EU", de los que 140 mil corresponden a España. El documento presentado por el Gobierno español en Bruselas el 30 de abril de 2021 se ha denominado "Plan de recuperación, transformación y resiliencia", y las empresas que soliciten la ayuda deberán presentar un "Proyecto estratégico para la recuperación y transformación económica" (PERTE). En este nuevo contexto de crisis generado por la pandemia, se abandona la imagen del "rescate" empleado durante la crisis del euro para evitar la imagen negativa ("invasión") de las decisiones de política económica que haya que tomar a cambio de dichas ayudas ("salvamento"). Todo ello, aunque igualmente se condicione su obtención al mismo tipo de reformas de la crisis anterior que, en el caso de España, se refieren al mercado laboral, las pensiones y los impuestos, entre otras. La forma en que los medios y la radio lo cuentan a los ciudadanos podrá ser estudiado en futuras investigaciones.

\section{Referencias}

Arrese, Á. (2015). Las metáforas de la crisis del euro en la prensa española. Communication \& Society, 28(2), 19-38. https://doi.org/10.15581/003.28.2.19-38

Arrese, Á. \& Vara, A. (2015). Divergent perspectives? Financial newspapers and the general interest press. En R. Picard (Ed.), The Euro Crisis in the News. Journalistic Coverage of the Economic Crisis and European Institutions (pp. 149-176). Reuters Institute for the Study of Journalism.

Buesa, M. (2011). Una política económica para España. En J. Velarde (Coord.), Lo que hay que hacer (pp. 79-98.). Editorial Actas.

Calsamiglia, H. \& Tusón, A. (1999). Las cosas del decir. Ariel.

Charteris-Black, J. \& Ennis, T. (2001). A comparative study of metaphor in Spanish and English financial reporting. English for Specific Purposes, 20, 249-266. https://doi.org/10.1016/S08894906(00)00009-0

Colmenarejo, J.P. \& Martínez-Costa, M.P. (2020). Contar la economía: Los recursos lingüísticos en la tertulia El equipo económico de La linterna de la Cadena COPE (mayo 2010-julio 2012). Estudios sobre el Mensaje Periodístico, 26(4), 1387-1398. https://doi.org/10.5209/esmp.69290

Colmenarejo, J.P. (2020). Crónica de la Crisis del Euro en España ¿Qué podemos aprender? Actualidad Económica, 102, 35-49. https://bit.ly/2XoVj10 
De Miguel, A. (2013). Hablando pronto y mal. Espasa.

De Sola Pueyo, J. (2021). Science in the media: the scientific community's perception of the COVID-19 media coverage in Spain. Journal of Science Communication, 20(02), A08. https://doi.org/ 10.22323/2.20020208.

Henderson, W. (1982). Metaphor in economics. Economics, 18(4), 147-153.

Hernández Gil, A. (2009, 29 de agosto). Las metáforas de la crisis. ABC. https://bit.ly/2Xoy5Sj

Herrera Soler, H. (2008). A metaphor corpus in business press headlines. Ibérica, 15, 51-70. https://bit.ly/37IHsPa

Juan, J. (2011). Nada es gratis. Destino.

Lakoff, G. \& Johnson, M. (1991). Metáforas de la vida cotidiana. Cátedra.

Llamas, C. (2005). Metáfora y la creación léxica. EUNSA.

Orts-Llopis, M.A. \& Almela Sánchez-Lafuente, Á. (2009). Translating the Spanish economic discourse of the crisis: Dealing with the inevitability of English loanwords. International Journal of English Studies, 9(3), 133-158. https://bit.ly/3orouTh

Pin, J. R. (2017). Bankia: respondiendo al reto. Caso de IESE Publishing, Universidad de Navarra.

Rodero, E. (2018). El peso creciente de la voz y el sonido para comunicar en la era digital: el protagonismo de la oralidad. Anuario AC/E de Cultura Digital. Acción Cultural Española, 80-94. https://bit.ly/3mpmfxX

Rodero, E. (2020). La radio: el medio que mejor se comporta en las crisis. Hábitos de escucha, consumo y percepción de los oyentes de radio durante el confinamiento por el Covid-19. Profesional de la Información, 29(3), e290306. https://doi.org/10.3145/epi.2020.may.06

Rodero, E., Pérez-Maillo, A. \& Espinosa de los Monteros, M. J. (2019). Ficción sonora en el ecosistema digital. En L-M. Pedrero Esteban \& J. M. García-Lastra-Núñez (Eds.), La transformación digital de la radio (pp. 151-173). Tirant Humanidades.

Rojo-López, A. M. \& Orts-Llopis, M. A. (2010). Metaphorical pattern analysis in financial texts: Framing the crisis in positive or negative metaphorical terms. Journal of Pragmatics, 42(12), 3300-3313. https://doi.org/10.1016/j.pragma.2010.06.001

Sarmiento, R. (2007). Sobre la lengua del discurso económico en los medios de comunicación. En R. Sarmiento \& F. Vilches (Eds.), Neologismos y sociedad del conocimiento: funciones de la lengua en la era de la globalización (pp. 111-129). Ariel.

Shiller, R. J. (2019). Narrative economics: How stories go viral and drive major economics. Princeton University Press. https://doi.org/10.1515/9780691189970

Soriano, C. (2012). La metáfora conceptual. En I. Ibarretxe-Antuñano \& J. Valenzuela (Dirs.), Lingüística cognitiva (pp. 97-121). Anthropos. https://bit.ly/3oubxrK

Strassmann, D. (1993). The stories of economics and the power of storytelling. History of Political Economy, 25(1), 147-165. https://doi.org/10.1215/00182702-25-1-147

Williams, A. (2013). Metaphor, media and the market. International Journal of Communication, 7, 14041417. https://bit.ly/3mANNAL

\section{Semblanza de los autores}

Juan Pablo Colmenarejo es Doctor en Comunicación Pública por la Universidad de Navarra. Es profesor invitado de la Facultad de Comunicación de la Universidad de Navarra y colabora con varios másteres de periodismo y comunicación de universidades españolas. Como periodista radiofónico tiene una experiencia de 30 años en radios privadas y públicas de España: Cadena 
Cope, Onda Cero, RTVE y Radio Televisión Madrid. Es columnista de varios medios, impresos y digitales.

María del Pilar Martínez-Costa es Doctora en Comunicación Pública por la Universidad de Navarra. Es Profesora Titular de Periodismo en la Facultad de Comunicación de la Universidad de Navarra donde imparte la asignatura Géneros y programas de radio. Ha publicado numerosos artículos académicos y ha sido investigadora principal de varios proyectos de investigación competitivos centrados en el estudio de los medios digitales, el audio digital y sus modelos narrativos, producción y distribución multiplataforma. 